\title{
First time reported in vitro pharmacological activity of Heliconia rostrata (Heliconiaceae) revealed its potency in pain management over a standard analgesic drug
}

\author{
Shatil Shahriar SM ${ }^{1}$, Sammy LA ${ }^{2}$, Rabbi F ${ }^{2}$, Bhuiyan $B^{2}$, Rahman MA ${ }^{2 *}$ and Nafiujjaman Md ${ }^{2,3 *}$ \\ ${ }^{1}$ Department of Chemical and Biology Engineering, Korea National University of Transportation, Chungju, South Korea \\ ${ }^{2}$ Department of Pharmacy, University of Development Alternative, Dhaka-1209, Bangladesh \\ ${ }^{3}$ Department of Nanomedicine, The Houston Methodist Research Institute, 6670 Bertner Ave, Houston, TX 77030, USA
}

\begin{abstract}
Heliconia rostrata, locally known as Jhulonto Chingri in Bangladesh, is generally found in several woodlands worldwide. Even though $H$. rostrata is mainly farmed for beautification, this plant has diverse medicinal practices around the world. Especially, the traditional medical healers are taking advantages of using several parts of this selected plant against different ailments for thousands of decades. By inspiring from those scientific validations and as a part of identifying and discovering drugs from natural sources, evaluating the analgesic property of this reported medicinal plant was the main phenomenon of this study. The in-vitro analgesic activity of the methanolic extract of Heliconia rostrata (MEHR) was studied in Swiss albino mice (experimental animal model) by the acetic acid-induced writhing model. Oral administration of MEHR significantly lessened 23.20,29.00, 46.38 and 58.00\% of the number of writhing respectively of an oral dose of $50,100,200$ and $400 \mathrm{mg} / \mathrm{kg}$. On the contrary, standard analgesic drug "Aspirin" minimized the number of writhing 39.13 and $55.06 \%$ at a dosage of 200 and $400 \mathrm{mg} / \mathrm{kg}$ respectively. Interestingly, $400 \mathrm{mg}$ and $200 \mathrm{mg}$ doses respectively of MEHR were more effective to reduce the mean number of abdominal constrictions in acetic acid-induced Swiss albino mice compared to the same doses of Aspirin. For the first time ever, our present study suggests that the MEHR can be considered as a potential natural source for the development of a new analgesic drug to relieve pain. Notably, we found that the MEHR is more potential and efficacious in comparison with the standard drug Aspirin for relieving pain.
\end{abstract}

\section{Introduction}

Pain is mainly associated with our nervous system; this physiological disorder occurs due to various unexpected conditions like a sting, burn, ache, or potential tissue damage and categorized into two folds such as acute and chronic [1]. Among them, acute pain comes suddenly due to sudden injury or inflammation or disease and lasting for a little time whereas chronic pain lasting for a long time of period and considered as incurable by medical treatment. In most cases, aspirin-like non-steroidal anti-inflammatory drugs pose their analgesic activity through selective and irreversibly inactivating cyclooxygenase enzyme to put down the production of prostaglandins by an either peripheral and/or central mechanism. According to the recent statistics of "Centers for Disease Control and Prevention", more than 50 million of adult populations in the USA suffered from chronic pain in 2016 and more than 19.5 million of USA pupils are affected by high impact chronic pain which is one of the most common cause to look for medical treatments $[2,3]$.

Natural drugs mainly originate from nature with various pharmacological effects and keep them in advance due to their lower adverse effect, high potency and efficacy, and safety use rather than pharmaceutical drug [4]. The plants are the most potent source of natural medicines and various parts of these plants are being used to treat many diseases by traditional medical practitioners not only in Bangladesh but also worldwide. Moreover, thousands of medicinal plants have identified effective because of their promising compounds that can act against cancer, diabetes, pain, inflammations, and so many diseases. For example, a number of herbs as well as spices, which are commonly used in the Indian subcontinent, are proved to have blood glucose reducing properties [5-7]. From last few decades, a series of research works have been studied that illustrates a correlation between the phytochemicals and improved disease conditions. Not only that, plant-based vaccination is gaining its popularity day by day because of their cost-effective production or stability in room temperature. An example would be, hepatitis B virus was successfully ingested into the transgenic plant to introduce plant-based oral hepatitis B virus surface antigen vaccine in the market that has the potential over traditional vaccines [8].

H. rostrata or falsa bird paradise or hanging lobster claw usually augments in the torrid garths as an inviter flower to many host birds, howsoever; their reported medicinal properties are very rare. Locally it is known as "Jhulonto Chingri" in Bangladesh and in Bolivia, it is known as "Patuju" and considers it as their national flower. It is found

${ }^{*}$ Correspondence to: $\mathrm{Md}$ Nafiujjaman, Department of Nanomedicine, the Houston Methodist Research Institute, 6670 Bertner Ave, Houston, TX 77030, USA, Phone No. +8801799467312; E-mail: mnafiujjaman@gmail.com

\#Co-Correspondence to: Md Atiqur Rahman, Department of Pharmacy, University OF Development Alternative, Dhaka-1209, Bangladesh, Tel. +8801819140328; E-mail: atiqur.r@uoda.edu.bd

Key words: Heliconia rostrata, methanolic extract, aspirin, analgesic activity, acute toxicity, phytochemicals

Received: December 10, 2018; Accepted: December 21, 2018; Published: December 28, 2018 
naturally and used to treat diabetes and diabetes associated-edema by the folk medicinal practitioner at the Sylhet division of Bangladesh [9]. Another ethnobotanical survey study reported that the leaf and seed of this plant are used to treat a headache, sprains, and pain by a medical practitioner who lived in a village near Rupsha River at Bagerhat District in Bangladesh [10]. Moreover, the rhizome of this plant is used to treat jaundice, intestinal pain and high blood pressure by the traditional people of Malaysia [11]. Interestingly, some Caribbean uses the leaves of this plant for wrapping food. On the other hand, Brazilians claimed that Heliconias' roots and seeds can be used against various diseases and they used this plant traditionally for centuries [12].

According to the best of our knowledge, no pharmacological study regarding the analgesic activity of $H$. rostrata has been carried out yet. This is why we selected Heliconia rostrata Ruiz and Pav. to find out new, cheap, effective and side effects free natural drugs targeting pain. We used the methanol extracts of the whole plant of $H$. rostrata to evaluate acetic acid-induced writhing test for analgesic activity in Swiss Albino mice. Notably, this test is a convenient test for measuring writhing number regarding pain management. The focus of this study was to evaluate the analgesic activity of methanolic extract of the full plant of $H$. rostrata and to make the comparison between standard analgesic drug "Aspirin" and methanolic extract of this plant. We also tried to identify the phytochemicals present in the $H$. rostrata which could be responsible for analgesic activities.

\section{Materials and methods}

\section{Plant material collection}

The whole plant of $H$. rostrata was collected from Rema Kalenga Wildlife Sanctuary in Sylhet Division, Bangladesh in November 2016. After collecting the plant, it was identified from the Bangladesh National Herbarium (BNH).

\section{Methanolic extract preparation}

First of all, the whole plants were cut into small pieces and thoroughly dried for pulverizing the whole plants into a fine powder. For preparing the extraction, the powder was mixed with methanol (1:5 ratios) for a period of more than 48 hours. At $50^{\circ} \mathrm{C}$ methanol was evaporated by using a water bath and then, the extract was preserved at $-20^{\circ} \mathrm{C}$ till use. Before starting oral administration in experimental animals, the extract was dissolved in Tween 20. The percent (\%) of plant yield was counted by the equation given below,

The percent $(\%)$ of plant yield $=\left(\mathrm{W}_{2}-\mathrm{W}_{1}\right) / \mathrm{W}_{0} \times 100$

Where, $\mathrm{W}_{2}=$ Weight of Plant Extract + Weight of Beaker, $\mathrm{W}_{1}=$ Weight of Beaker, and $\mathrm{W}_{0}=$ Weight of Crude Powder

\section{Chemicals and drugs}

Aspirin was collected from Square Pharmaceuticals Ltd., Bangladesh. Other chemicals including methanol $\left(\mathrm{CH}_{3} \mathrm{OH}, 99 \%\right)$, DMSO and tween 20 (as suspending agents collected from Gaylord Chemicals, USA) and, Savlon (as an antiseptic collected from GlaxoSmithKline). An analytical grade presented in all other chemicals.

\section{Animals}

3-4 weeks old Swiss albino mice as laboratory animals were collected from the International Centre for Diarrhoeal Disease Research, Bangladesh (ICDDRB). Estimated weight of 18-25 gram mice from both sexes was used in this present study. An adaptation required for a period of more than three days, before using the mice to actual experiments. In these periods of time, the cages were kept in wellventilation and used to locate the animal under hygienic conditions in the animal house of the University Of Development Alternative, Dhaka, Bangladesh. According to the instruction of ICDDRB, the room temperature was maintained at $25-27^{\circ} \mathrm{C}$ and the relative humidity was in the range of $50-55 \%$. Standard mouse chow and water was given to mice as food till experiments. The approval from the Institutional Animal Ethical Committee of the University of Development Alternative, Dhaka, Bangladesh had governed the study.

\section{Evaluation of analgesic activity}

The in vitro analgesic activity of the methanolic extract of $H$. rostrata was performed in Swiss albino mice (experimental mice model) following the same protocol as previously described by Akmal Hosain Nipu et al. [13]. In brief, experimental mice were divided into seven groups where each group contained five mice. Group-1 was used as a control and was provided vehicle only. On the other hand, group-2 and group-3 administered standard analgesic drug "Aspirin" at a dose $200 \mathrm{mg} / \mathrm{kg}$ and $400 \mathrm{mg} / \mathrm{kg}$ respectively. In addition, the remaining groups (group 4-7) were received a methanolic extract of $H$. rostrata at a dosage of 50, 100, 200 and $400 \mathrm{mg} / \mathrm{kg}$, respectively. All substances were orally administrated. After 1 hour of administration of the standard drug (group 2 and group 3) or MEHR (from group 4 to 7), 1\% acetic acid was intraperitoneally injected into all mice at a dose of $10 \mathrm{ml}$ per $\mathrm{kg}$. Next, to ensure bioavailability and onset of chemical action for inducing pain in mice, the mice were observed for 5 minutes which was characterized by abdominal constrictions or writhes as previously described by Ahamed Ismail Hossain et al. [14]. After this period, the number of abdominal constrictions was counted for 10 minutes. Finally, the percentage of inhibitions of abdominal constrictions which indicate the degree of analgesic effect was calculated using the formula given below:

\section{The percent of inhibition $=(1-\mathrm{We} / \mathrm{Wc}) \mathrm{X} 100$}

Where "We" represents the number of abdominal constrictions or writhings in aspirin or MEHR administrated mice (Groups 2-7),

and "Wc" represents the number of abdominal constrictions or writhings of control mice (Group 1).

\section{Acute toxicity}

Thirty mice (3-4 weeks old) from both sexes (male and female) were used to perform acute toxicity test according to the previously described manner with few modifications [15]. In brief, mice were separated into six groups, where each group contained five mice. The average weight of experimental mice was $19 \mathrm{mg}$. The methanolic extract of $H$. rostrata was administrated at a dose of 100, 200, 400, 600, 800 and $1000 \mathrm{mg} / \mathrm{kg}$ from group-1 to group-6, respectively by gavaging. Before performing acute toxicity test, experimental mice were 12 hours fasted and after administration of various doses of MEHR to the selected groups, animals were observed for 72 hours for toxicity related clinical sign like changes in behavior, alertness, restlessness, muscle convulsion, tremor, touch response, torch response, pain response, gripping, writhing, urination, salivation, skin color, food intake, water intake, grooming and mortality. During the observation period, regular food and water were given to mice on a daily basis.

\section{Phytochemical analysis}

Alkaloid test: To identify the presence of alkaloid in Heliconia rostrata, $0.5 \mathrm{gm}$ of MEHR was dissolved in $5 \mathrm{ml}$ of $1 \%$ of $\mathrm{HCl}$ by using a 
conical flask. Next, the conical flask was placed on a water bath for 3-4 minutes at $90^{\circ} \mathrm{C}$. Finally, the solution was filtered followed by addition of Wagner reagent (Standard solution of I2 in KI). The formation of brown precipitation indicated the presence of alkaloid.

Flavonoid test: Small amount of methanolic extract of Heliconia rostrata was taken in a test tube followed by addition of a few drops of distilled water. Finally, 200 microliters of concentrated HCL acid was added to the extract solution. Quick formation of red color indicated the presence of flavonoids.

Steroid test: Liebermann-Burchard reaction was performed to carry out the steroid test. Initially, MEHR was dissolved in chloroform and wait for 2-3 hours. Next, the solution was evaporated by using a water bath at $55^{\circ} \mathrm{C}$. Finally, $1 \mathrm{ml}$ of concentrated $\mathrm{H}_{2} \mathrm{SO}_{4}$ was drop wisely added to the solution. The formation of red color indicated the presence of flavonoids.

Saponin test: $0.5 \mathrm{gm}$ of methanolic extract was taken with water in a test tube and vigorously shaken the test tube followed by the Frothing test. Persistent frothing developed and its stability in heating indicated the presence of saponins.

\section{Result}

\section{Plant identification \& yield (\%)}

The scientific classification of this plant was confirmed by Bangladesh National Herbarium (Table 1) and the accession number of this Heliconiaceae family's plant was 43730 (Figure 1). We also confirmed various ethnomedicinal properties (reported) of Heliconia rostrate (Figure 2) from various literature [9-12]. The final weight of the plant extract was $16.77 \mathrm{~g}$ whereas the percentage yield of crude extract from the sample of Heliconia rostrata was 5.47.

Table 1. Scientific classification of Heliconia rostrata

\begin{tabular}{|c|c|}
\hline Kingdom & Plantae \\
\hline Subkingdom & Trachobinota \\
\hline Superdivision & Spermatophyta \\
\hline Division & Magnoliophyta \\
\hline Class & Liliopsida \\
\hline Subclass & Zingiberidae \\
\hline Order & Zingiberales \\
\hline Family & Heliconiaceae \\
\hline Genus & Heliconia \\
\hline Species & Heliconia rostrata Ruize \& Pav. \\
\hline
\end{tabular}
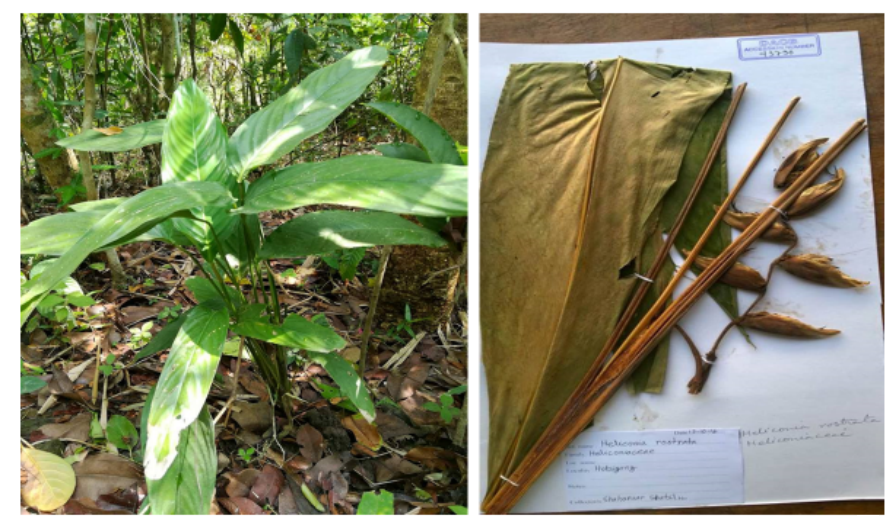

Figure 1. Heliconia rostrata (left panel; the photo was taken from Remakalenga wildlife sanctuary in Sylhet division) and its primary identification (right panel)

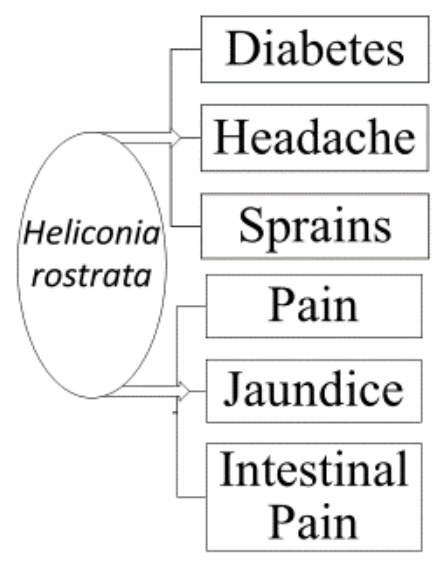

Figure 2. Folkloric uses of Heliconia rostrata

\section{Analgesic activity}

The analgesic effects of the methanolic extract of Heliconia rostrata and reference drug aspirin by acetic acid-induced abdominal writhing in Swiss albino mice is figured out in Table 2. Both MEHR (50, 100, 200 and $400 \mathrm{mg} / \mathrm{kg}$ ) and standard drug aspirin (200 and $400 \mathrm{mg} /$ $\mathrm{kg}$ ) showed significant and dose-dependent analgesic activity on the acetic acid-induced abdominal constrictions in mice. In details, after administration of MEHR at a dose of 50, 100, 200 and $400 \mathrm{mg} /$ $\mathrm{kg}$, the reduced number of writhings were 23.20, 29.00, 46.38, and $58.00 \%$ respectively, when compared to control group. On the other hand, reference drug Aspirin, when administrated at a dosage of 200 and $400 \mathrm{mg} / \mathrm{kg}$, down-regulated the number of writhings at 39.13 and $55.06 \%$ respectively, compared to the control group. However, $400 \mathrm{mg} /$ $\mathrm{kg}$ dose of MEHR exhibited better analgesic activity than the given doses of Aspirin (both 200 and 400mg/Kg BW). Nevertheless, $200 \mathrm{mg} /$ $\mathrm{kg}$ dose of MEHR also showed approximately 1.2 times better result in comparison with an equal amount of Aspirin.

\section{Acute toxicity test}

Acute toxicity test was studied to evaluate the specific dose levels that can sake of mortality. Various toxicological signs including changes in behavior, alertness, restlessness, muscle convulsion, tremor, touch response, torch response, pain response, gripping, writhing, urination, salivation, skin color, food intake, water intake and grooming, and survival analysis were regarded during 72 hours of the examination period. In conformity with the result, MEHR up to $1000 \mathrm{mg} / \mathrm{kg}$ dose showed no toxicity related symptoms or mortality during the entire time of acute toxicity test. Hence, the median lethal dose (LD 50) would be more than $1000 \mathrm{mg} / \mathrm{kg}$. Here, Table 3 represents the acute toxicity test data of MEHR $(100,200,400,600,800$, and $1000 \mathrm{mg} / \mathrm{kg})$ in thirty Swiss albino mice (the control group did not receive any treatment); where, " $\checkmark$ " and " $\mathrm{X}$ " signs indicate normal parameter and absent parameter respectively, and zero sign " 0 " means Nil.

\section{Phytochemical analysis}

Medicinal plants usually use to cure many diseases due to the presence of various phytochemicals that have potential to act against several ailments. To identify why Heliconia rostrata shows analgesic activities, we studied a number of phytochemical analysis test. The phytochemical analysis test expressed the availability of four phytochemicals (alkaloids, flavonoids, steroids, and saponins) in the methanolic extract of $\mathrm{H}$. rostrate as active pharmaceutical chemical 
Shatil Shahriar SM (2018) First time reported in vitro pharmacological activity of Heliconia rostrata (Heliconiaceae) revealed its potency in pain management over a standard analgesic drug

Table 2. Data chart of the analgesic study of MEHR

\begin{tabular}{|c|c|c|c|}
\hline Treatment & Dose $\mathbf{( m g / k g ) ~ B W}$ & Mean Number of Abdominal constrictions & \% of Inhibition \\
\hline Control & $10 \mathrm{ml}$ & - \\
\hline Aspirin & $200 \mathrm{mg}$ & $4.2 \pm 0.55$ \\
\hline Aspirin & $400 \mathrm{mg}$ & $3.1 \pm 0.67$ \\
\hline MEHR & $50 \mathrm{mg}$ & $5.3 \pm 0.62$ & $39.13 \%$ \\
\hline MEHR & $100 \mathrm{mg}$ & $4.9 \pm 0.61$ & $55.06 \%$ \\
\hline MEHR & $200 \mathrm{mg}$ & $3.7 \pm 0.47$ \\
\hline MEHR & $400 \mathrm{mg}$ & $2.9 \pm 0.41$ \\
\hline
\end{tabular}

Table 3. Effect of MEHR on acute toxicity test in Swiss albino mice

\begin{tabular}{|c|c|c|c|c|c|c|c|c|}
\hline \multirow{2}{*}{ SL No } & \multirow{2}{*}{ Clinical Sign } & \multirow{2}{*}{ Before Treatment } & \multicolumn{6}{|c|}{ After Treatment } \\
\hline & & & $100 \mathrm{mg} / \mathrm{kg}$ & $200 \mathrm{mg} / \mathrm{kg}$ & $400 \mathrm{mg} / \mathrm{kg}$ & $600 \mathrm{mg} / \mathrm{kg}$ & $800 \mathrm{mg} / \mathrm{kg}$ & $1000 \mathrm{mg} / \mathrm{kg}$ \\
\hline 1 & Behavior & $\checkmark$ & $\checkmark$ & $\checkmark$ & $\checkmark$ & $\checkmark$ & $\checkmark$ & $\checkmark$ \\
\hline 2 & Alertness & $\checkmark$ & $\checkmark$ & $\checkmark$ & $\checkmark$ & $\checkmark$ & $\checkmark$ & $\checkmark$ \\
\hline 3 & Restlessness & $\mathrm{X}$ & $\mathrm{X}$ & $\mathrm{X}$ & $\mathrm{X}$ & $\mathrm{X}$ & $\mathrm{X}$ & $\mathrm{X}$ \\
\hline 4 & Convulsion & $\mathrm{X}$ & $\mathrm{X}$ & $\mathrm{X}$ & $\mathrm{X}$ & $\mathrm{X}$ & $\mathrm{X}$ & $\mathrm{X}$ \\
\hline 5 & Tremors & $\mathrm{X}$ & $\mathrm{X}$ & $\mathrm{X}$ & $\mathrm{X}$ & $\mathrm{X}$ & $\mathrm{X}$ & $\mathrm{X}$ \\
\hline 6 & Touch Response & $\checkmark$ & $\checkmark$ & $\checkmark$ & $\checkmark$ & $\checkmark$ & $\checkmark$ & $\checkmark$ \\
\hline 7 & Torch Response & $\checkmark$ & $\checkmark$ & $\checkmark$ & $\checkmark$ & $\checkmark$ & $\checkmark$ & $\checkmark$ \\
\hline 8 & Pain Response & $\checkmark$ & $\checkmark$ & $\checkmark$ & $\checkmark$ & $\checkmark$ & $\checkmark$ & $\checkmark$ \\
\hline 9 & Gripping & $\checkmark$ & $\checkmark$ & $\checkmark$ & $\checkmark$ & $\checkmark$ & $\checkmark$ & $\checkmark$ \\
\hline 10 & Writhing & $\mathrm{X}$ & $\mathrm{X}$ & $\mathrm{X}$ & $\mathrm{X}$ & $\mathrm{X}$ & $\mathrm{X}$ & $\mathrm{X}$ \\
\hline 11 & Urination & $\checkmark$ & $\checkmark$ & $\checkmark$ & $\checkmark$ & $\checkmark$ & $\checkmark$ & $\checkmark$ \\
\hline 12 & Salivation & $\checkmark$ & $\checkmark$ & $\checkmark$ & $\checkmark$ & $\checkmark$ & $\checkmark$ & $\checkmark$ \\
\hline 13 & Skin Color & $\checkmark$ & $\checkmark$ & $\checkmark$ & $\checkmark$ & $\checkmark$ & $\checkmark$ & $\checkmark$ \\
\hline 14 & Food Intake & $\checkmark$ & $\checkmark$ & $\checkmark$ & $\checkmark$ & $\checkmark$ & $\checkmark$ & $\checkmark$ \\
\hline 15 & Water Intake & $\checkmark$ & $\checkmark$ & $\checkmark$ & $\checkmark$ & $\checkmark$ & $\checkmark$ & $\checkmark$ \\
\hline 16 & Grooming & $\mathrm{X}$ & $\mathrm{X}$ & $\mathrm{X}$ & $\mathrm{X}$ & $\mathrm{X}$ & $\mathrm{X}$ & $\mathrm{X}$ \\
\hline 17 & Mortality & N/A & 0 & 0 & 0 & 0 & 0 & 0 \\
\hline
\end{tabular}

ingredients. The results are abridged in Table 4 . In details, after adding the Wagner reagent in the filtered solution, the formation of brown precipitation indicated the presence of alkaloid. On the contrary, after dropwise adding of concentrated $\mathrm{HCl}$ and $\mathrm{H}_{2} \mathrm{SO}_{4}$ to the two separate solutions of flavonoid and steroid tests, the formation of red color indicates the presence of flavonoid and steroid in the MEHR respectively. Moreover, in the saponin test, persistent frothing developed and its stability in heating indicated the presence of saponins.

\section{Discussion}

In the present study, we evaluated the analgesic effects of methanolic extract of Heliconia rostrata and the result was beyond the expectation. Acetic acid induced abdominal constrictions of Swiss albino mice which are observed visually and useful for screening of analgesic activity as reported before [16]. The methanolic extract of $H$. rostrata was administrated at a dose of 50,100, 200 and $400 \mathrm{mg} / \mathrm{kg}$ separately into mice by gavaging and exhibited a significant analgesic activity by decreasing the abdominal constrictions in the acetic acid-induced writhing model. According to our result, MEHR at $200 \mathrm{mg} / \mathrm{Kg}$ BW dose inhibited the abdominal constriction of $46.38 \%$ compared with 200 $\mathrm{mg} / \mathrm{kg}$ BW dose of the reference drug Aspirin which inhibited 39.13\%. More surprisingly, when we doubled the dose of MEHR by means of $400 \mathrm{mg} / \mathrm{kg}$ dose concentration, then the percentage of the inhibition of writhing number was raised to 58 compared to the control group. In addition, Aspirin reduced the abdominal constrictions at $55.06 \%$ at 400 $\mathrm{mg} / \mathrm{kg}$ dose concentration compared to the control group. Therefore, 200mg \& $400 \mathrm{mg} / \mathrm{kg}$ BW doses of MEHR showed a better analgesic activity than a standard analgesic drug "Aspirin" at the same doses respectively (Figure 3A). In addition, MEHR reduces the mean number of abdominal constrictions at 5.3, 4.9, 3.7, and 2.9 after oral gavaging
Table 4. Phytochemical analysis data

\begin{tabular}{|c|c|}
\hline Phytochemicals & Availability \\
\hline Alkaloids & Present \\
\hline Flavonoids & Present \\
\hline Steroids & Present \\
\hline Saponins & Present \\
\hline
\end{tabular}

of $50 \mathrm{mg}, 100 \mathrm{mg}, 200 \mathrm{mg}$ and 400mg of MEHR, respectively, whereas the reference drug Aspirin can downregulate the number of abdominal constrictions at 4.2 and 3.1 after peritoneal administration (Figure 3B). We found, $400 \mathrm{mg} / \mathrm{kg} \mathrm{BW}$ dose of MEHR was 1.25 times more effective compared to the same dose of Aspirin in the experimental murine model whereas $200 \mathrm{mg} / \mathrm{kg}$ BW dose of MEHR was 1.4 times more effective than $200 \mathrm{mg} / \mathrm{kg}$ BW dose of Aspirin

In our recent study, we performed acute toxicity test and the result suggested that MEHR didn't show any toxicity even in $1000 \mathrm{mg} / \mathrm{kg}$ concentration. According to the result, we did not find any alterations in changes of behavior, alertness, restlessness, muscle convulsion, tremor, touch response, torch response, pain response, gripping, writhing, urination, salivation, skin color, food intake, water intake and grooming in comparison with control group. In spite of that, the survival rate of mice in all groups was $100 \%$ during 72 hours of study (Figure 4).

We also tried to identify some phytochemicals in this plant and found alkaloid, flavonoid, steroid, and saponin were presented in this plant samples (Table 4) where all of these photochemical had already been identified for their analgesic activity [17-20]. Be specifically, koumine is a type of alkaloids, which is responsible for reducing postoperative pain. On the other hand, Flavonoids can 

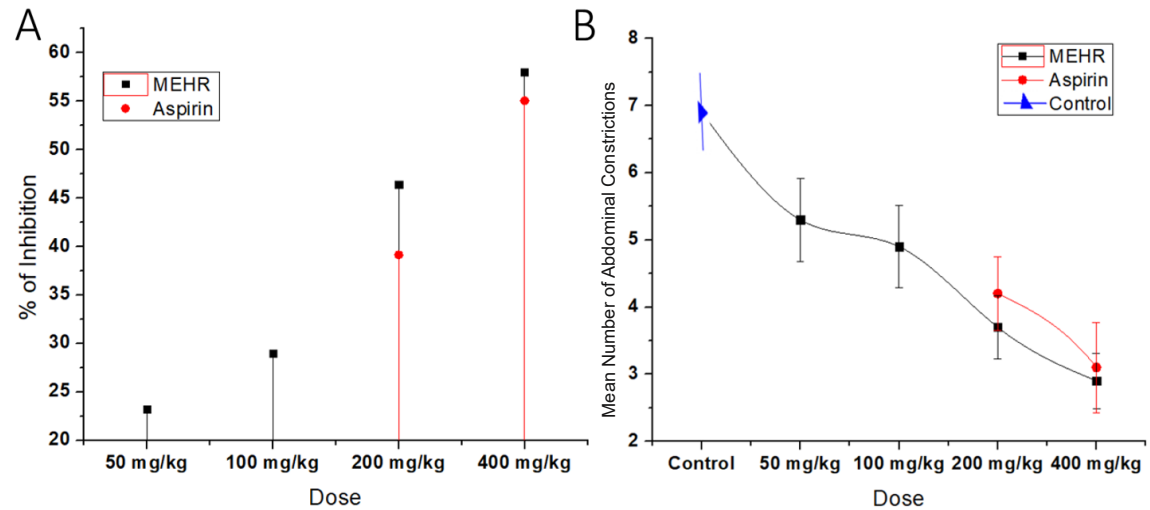

Figure 3. Comparative Analgesic Study between MEHR and Aspirin. (A. Percentages of inhibition by various doses of MEHR and Aspirin, B. Mean number of abdominal constrictions for various doses of MEHR and Aspirin)

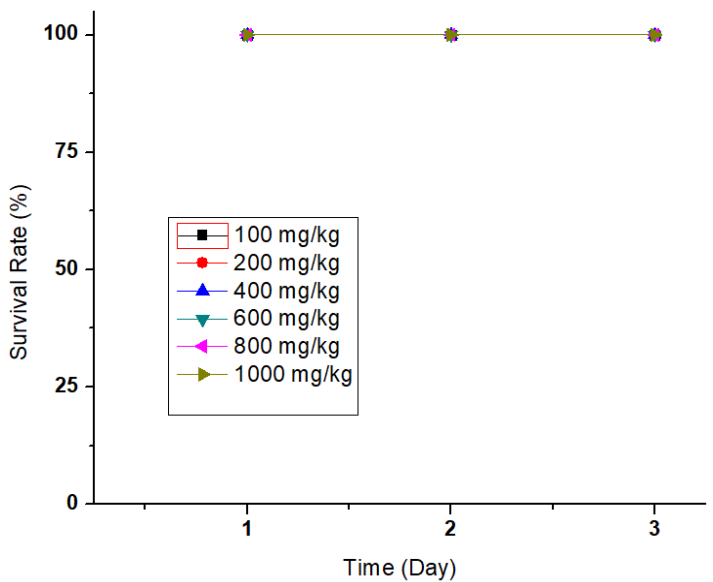

Figure 4. Survival Analysis of Swiss Albino mice with various doses of MEHR

inhibit various mediators like serotonin, histamine, nitric oxide, reactive oxygen species, which are derived from plasma of cell and reduced the inflammation as well as pain [19]. In addition, steroids are the most prescribed drug to reduce pain for cancer patients even though these types of drugs have their own limitations like severe side effects and adverse effects [20]. Their main analgesic mechanism is to downregulate the inflammation and cancer assisted edema. In this case, saponins generally can put down the synthesis of prostaglandins by inhibiting the enzymatic activities of phosphodiesterases, protein kinase $\mathrm{C}$, phospholipase A2, and protein tyrosine kinases.

In our study, for the first time, we claimed that as $200 \mathrm{mg}$ and $400 \mathrm{mg}$ doses of MEHR exhibited a satisfactory result against pain management in the acetic acid-induced writhing model in mice. This result is very closely related to the presence of secondary metabolites such as alkaloids, flavonoids, steroids, and saponins in Heliconia rostrate. Importantly, our study was based on oral delivery, even; free plant extract shows very poor result due to the extreme acidic environment of GIT. Hence, as naked therapeutics MEHR exhibits very good result compare to reference drug Aspirin. In near future, we may consider MEHR as a side effect free natural potential analgesic drug.

\section{Conclusion}

The natural product is a vast topic that has a big scope to discover and develop new drug component. On the basis of drug discovery, we performed our study to identify the analgesic activity of Heliconia rostrata plant. For the first time, we evaluated the analgesic activity of the methanolic extract of $H$. rostrata that revealed a significantly better result rather than analgesic drug Aspirin with no related toxicity whereas the oral LD50 of the MEHR was more than $1000 \mathrm{mg} / \mathrm{kg}$. The presence of four phytochemicals, which are already reported for analgesic activity which are responsible for such analgesic activities. The result of our study suggested that the extract of this plant can relieve pain and further research can make this plant extract as a potential analgesic drug.

\section{Author's contributions}

SMSS and MN designed this study. SMSS, LAS, MFR, and MBV conducted these experiments according to the supervision of $\mathrm{MN}$. SMSS and MFR wrote the manuscript draft which was read and edited by MN and MAR.. All authors read and approved the final version of the manuscript.

\section{Funding}

“This research received no external funding

\section{Acknowledgment}

The authors are thankful to Md. Rifat Shah and Md. Emran Hossen for their help.

\section{Conflicts of interest}

The authors report that they have no conflicts of interest. The authors alone are responsible for the content and writing of this article. 


\section{References}

1. Melnikova I (2010) Pain market. Nat Rev Drug Discov 9: 589-590. [Crossref]

2. Floyd E. Bloom. Analgesic DRUG. ENCYCLOPEDIA BRITANNICA. Retrieved from: https://www.britannica.com/science/analgesic

3. Dahlhamer J, Lucas J, Zelaya C, Nahin R, Mackey S, et al. (2018) Prevalence of Chronic Pain and High-Impact Chronic Pain Among Adults - United States, 2016. MMWR Morb Mortal Wkly Rep 67: 1001-1006. [Crossref]

4. Karimi A, Majlesi M, Rafieian-Kopaei M (2015) Herbal versus synthetic drugs; beliefs and facts. $J$ Nephropharmacol 4: 27-30. [Crossref]

5. Shatil Shahriar SM, Rahmatullah M (2016) Oral glucose tolerance test in mice with a polyherbal formulation diabeto-MLF. World J Pharm Pharm Sci 5: 199-206.

6. Shatil Shahriar SM, Rahmatullah M (2016) Evaluation of antihyperglycemic activity of a polyherbal formulation diabeto-VLC. World J Pharm Pharm Sci 5: 191-198

7. Shatil Shahriar SM, Shoma JF, Rahmatullah M (2017) Oral glucose tolerance test (OGTT) with whole plants of Alocasia fornicata Roxb (Araceae). World J Pharma Res $6(12)$.

8. Nazmul Hasan M, Shatil Shahriar SM (2018) Oral Vaccines-Types, Delivery Strategies, Current and Future Perspectives. Biomed J Sci \& Tech Res 11(2).

9. Shatil Shahriar SM, Be-nazir Farzana, Rahmatullah M (2017) Heliconia rostrata Ruiz \& Pav. (Heliconiaceae)-A previously unreported plant for treatment of diabetes and diabetes-induced edema. Asian J of Pharmacog 1:51-54.

10. Md. Ariful Haque Mollik, Azmal Ibna Hassan, Tridib Kumar Paul, Mariz Sintaha, Hime Nahreen Khaleque, et al. (2010) A survey of medicinal plant usage by folk medicinal practitioners in two villages by the Rupsha River in Bagerhat District, Bangladesh. American-Eurasian Journal of Sustainable Agriculture 4: 349-356.
11. Gunjan M, Karna L, Dayalan K, Sasigaran P (2012) A review and search of phytomedicine used by traditional people of Malaysia (Ipoh, Perak). Int J Phytother Res 21:26-41.

12. John \& Jacqs Garden, The exotic blooms of tropical Heliconia species. Direct Link http://www.jaycjayc.com/heliconia-species/\#.Wnmb-9SgfIU

13. Akmal Hosain Nipu, Akter S, Rahmatullah Md (2018) Analgesic activity studies with a polyherbal formulation containing plant parts of Allium cepa, Allium sativum and Curcuma zedoaria. Eur J Pharm Med Res 5: 117-120.

14. Hossain AI, Faisal M, Rahman S, Jahan R, Rahmatullah M (2014) A preliminary evaluation of antihyperglycemic and analgesic activity of Alternanthera sessilisaerial parts. BMC Complement Altern Med 14:169. [Crossref]

15. Lorke D (1983) A new approach to practical acute toxicity testing. Arch Toxicol 54 275-287. [Crossref]

16. Raquibul SM, Hossain MM, Aktar R, Jamila M, Mazumder MEH, Alam MA, et al. (2010) Analgesic Activity of the Different Fractions of the Aerial Parts of Commenila Benghalensis Linn. Int J Pharmaco 6:63-67.

17. Bo-Jun Xiong, Ying Xu, Gui-Lin Jin, Ming Liu, Jian Yang \& Chang-Xi Yu (2017) Analgesic effects and pharmacologic mechanisms of the Gelsemium alkaloid koumine on a rat model of postoperative pain. Scientific Reports. volume 7, Article number: 14269 (2017)

18. Waldiceu A, Fabiana, Baracat MM, Georgetti SR, Cardoso R, et al. (2012) Chapte 9 - Flavonoids as Anti-Inflammatory and Analgesic Drugs: Mechanisms of Action and Perspectives in the Development of Pharmaceutical Forms. Studies in Natural Products Chemistry $36: 297-330$.

19. Shehu A, Olurishe TO, Zezi AU, Ahmed A (2016) Saponin and flavonoid-rich fraction of Laggera aurita Linn. F. produce central analgesia in murine models of pain. Niger J Pharm Sci 15:60-69.

20. Vyvey M (2010) Steroids as pain relief adjuvants. Can Fam Physician 56: 1295-1297, e415. [Crossref]

Copyright: (C2018 Shatil Shahriar SM. This is an open-access article distributed under the terms of the Creative Commons Attribution License, which permits unrestricted use, distribution, and reproduction in any medium, provided the original author and source are credited. 